\title{
Ability of an Incompatible Race of Erysiphe graminis hordei to Induce an Accessibility to the Same Race in Heat-Predisposed Barley Leaves
}

\author{
Seiji Ouchi*, Hideto Nakabayashi**, and Hachiro OKu* \\ 大内成志・中林英人・奥 八郎・熱処理オオムギ葉における不親和性うどんと \\ 病菌の受容性誘導能
}

In previous studies, we have demonstrated that preliminary inoculation with a compatible race of Erysiphe graminis DC. hordei Marchal induced in barley leaves an accessibility to primarily incompatible races, while earlier inoculation with an incompatible race induced an inaccessibility to a compatible race ${ }^{1,2,3,4,5)}$. In another series of study, we also showed that heat treatment rendered barley leaves susceptible to incompatible races, although the heat-shock effect disappeared within a certain periord of time ${ }^{6,7)}$. A question consequently followed was whether or not the incompatible race invaded in heat-predisposed leaves could induce an accessibility while heat-shock remained effective.

In this communication, we provide evidence that the incompatible race is indeed capable of inducing accessibility in the invaded leaves that had been predisposed by heat-shock.

An isogenic line from Hordeum vulgare L. cv. Kobinkatagi $\times$ Hordeum spontaneum nigrum (immune to any race found in Japan) was grown in potted soil in a phytotron at $20 \mathrm{C}$ for 10 days. Seedlings of a uniform size (5 seedlings per pot) were incubated at $45 \mathrm{C}$ for $60 \mathrm{~min}$. After cooling at room temperature for $1 \mathrm{hr}$, middle part of abaxial surface of leaves was inoculated with conidia of race 1 (incompatible) of Erysiphe graminis hordei and incubated in an artificial-light illuminated phytotron at $20 \mathrm{C}$. The first inoculum was removed with a $3 \mathrm{hr}$-interval by rubbing with a wet cotton ball, and 30 min later respectively the leaves were challenge-inoculated with the same race at the same site. The affinity indices of the challenger were estimated $48 \mathrm{hr}$ after the second inoculation respectively.

* College of Agriculture, Okayama University, Okayama, Japan. 岡山大学農学部

** Shimonoseki West Senior High School, Toyoura-cho, Yamaguchi, Japan.

山口県立下関西高等学校

This work was supported by The Ministry of Education, Science and Culture, grant (Nos. 156033, 136006, and 811209)

1) Ouchi, S. et al. (1974). Phytopathol. Z. 79: 24-34. 2) Ouchi, S. et al. (1974). Phytopathol. Z. 79: 142-154. 3) Ouchi, S. et al. (1976). Phytopathology 66: 901-905. 4) Ouchi, S. et al. (1976). Physiol. Pl. Pathol. 9: 25-32. 5) Ouchi, S. et al. (1976). In Biochemistry and Cytology of Plant Parasite Interaction (Tomiyama, K. et al. eds.) Kodansha, Ltd., Tokyo, pp 181-194. 6) Ouchi, S. et al. (1975). Ann. Phytopath. Soc. Japan 41: 453-460. 7) Ouchi, S. et al. (1976) Ann. Phytopath. Soc. Japan 42: 131-137. 


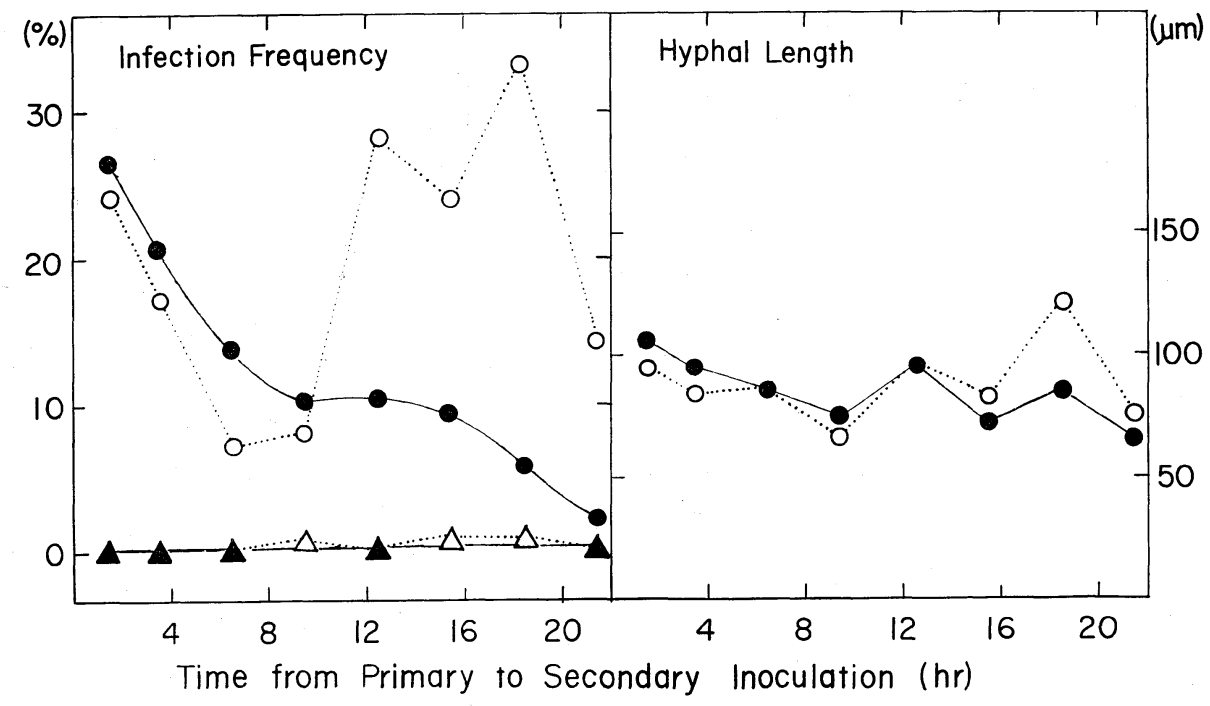

Figure 1. Infection frequency and hyphal growth of Erysiphe graminis hordei, rece 1 , on incompatible barley leaves which had been previously heat-shocked and inoculated with the same race.

Leaves were predisposed at $45 \mathrm{C}$ for $60 \mathrm{~min}$ and inoculated with race 1 after cooling $(1 \mathrm{hr})$. The leaves were then challenged with the same race $1.5,3.5,6.5$, $9.5,12.5,15.5,18.5$, and $21.5 \mathrm{hr}$ respectively after the primary inoculation. Infection indices were estimated $48 \mathrm{hr}$ after the challenge. Non-heated-none-race $1(\boldsymbol{\Delta})$; nonheated-race 1 -race $1(\triangle)$; heated-none-race $1(\bigcirc)$; heated-race 1 -race $1(\bigcirc)$.

The result is shown in Fig. 1. The primary inoculum that established infection in leaves which had been heat-predisposed was apparently able to induce an accessibility in the leaves, as evidenced by a significant increase of infection frequency, during the early phase of primary interaction, $12-18 \mathrm{hr}$ after the first inoculation. The infection frequency of the challenger, however, decreased significantly when it was inoculated $21 \mathrm{hr}$ after the primary inoculation. Similar experiments with longer inoculation interval indicated that there was no significant increase in the infection frequency of the second inoculum when challenge inoculation was made $35 \mathrm{hr}$ after the primary inoculation. There was essentially no significant difference in the length of secondary hyphae between primary fungus-inoculated and non-inoculated leaves excepting the case where double inoculation was made with an $18 \mathrm{hr}$ interval, supporting the previous idea that powdery mildew fungus, irrespective of its compatibility to the host, becomes capable of extending growth once it established infection in the host cells.

These results were interpreted as follows: Heat treatment at a certain level of dosage breaks the primary defense mechanism of plant cells, that probably involves recognition of pathogen and subsequent conditioning either to accessibility or inaccessibility, rendering the cells accessible to an incompatible race or nonpathogen. The first incompatible fungus that succeeded in establishing infection changes physiological state of cells in the neighborhood to be accessible to the subsequently inoculated fungus. However, as the heat-shock effect disappears with time after treatment ${ }^{6)}$, 
the fraction of cells that could be conditioned by the primary fungus toward accessibility should decrease expontially. Thus the primary fungus may probably be recognized by the repaired host cells as an unassociable entity, hence becomes unable to induce accessibility as was illustrated by the decreased infection of the challenger fungus that was inoculated 21 or more $\mathrm{hr}$ after the primary race.

The present result provides another type of evidence for the idea that the fungus that succeeded in establishing parasitic relation with host cells is capable of, in part, suppressing the derepressive operation of genes for disease resistance, and seems to explain how incompatible powdery mildew fungus becomes capable of growing and consequently producing subsolitary conidia on the heat-predisposed leaves.

We thank Professor U. Hiura, Institute for Agricultural and Biological Sciences, Okayama University, for his kind gift of the isogenic line used in this experiment. We also thank Mr. T. Shiraishi for his technical assistance.

(Received September 3, 1976) 